\title{
Biopsychosocial factors of Axis II of the Research Diagnostic Criteria for Temporomandibular Disorders in individuals with muscular temporomandibular disorder and migraine
}

\author{
Fatores biopsicossociais do Eixo Il dos Critérios de Diagnóstico para Pesquisa das Desordens \\ Temporomandibulares em indivíduos com disfunção temporomandibular muscular e migrânea
}

Claudia Branco Battistella ${ }^{1}$, Thatiana Bastos Guimarães ${ }^{1}$, Camila Leite Quaglio' ${ }^{1}$, Mariana Brandão Ferreira-Cabrini ${ }^{1}$, Dinamar Aparecida Gaspar-Martins ${ }^{1}$, Neil Ferreira Novo², Yara Juliano², Deusvenir de Souza Carvalho ${ }^{3}$, Antonio Sérgio Guimarães ${ }^{4}$, Luis Garcia Alonso ${ }^{1}$

\section{ABSTRACT}

BACKGROUND AND OBJECTIVES: To relate biopsychosocial variables of Research Diagnostic Criteria for Temporomandibular Disorders to groups of patients with temporomandibular disorders, temporomandibular disorders and migraine and a control group.

METHODS: This is a cross-sectional observational study where 280 consecutive patients were evaluated and distributed in three groups: group I (140 control individuals); group II (65 individuals with muscle temporomandibular disorders) and group III (75 individuals with migraine and muscle temporomandibular disorders). Exclusion criteria were individuals with clinical history of muscle inflammatory processes, muscle spasms, contractures and acute temporomandibular joint traumatic injury.

RESULTS: Group III individuals had association with severe depression $(\mathrm{p}<0.001)$, level 4 in pain severity $(\mathrm{p}=0.004)$, unspecific physical symptoms without severe pain $(\mathrm{p}<0.0001)$ and unspecific symptoms with severe pain $(\mathrm{p}<0.00001)$. There has been significant difference between females and males in group III $(\mathrm{Z}=2.59 ; \mathrm{p}=0.001)$, with longer pain duration among females. The percentage of females in group III was significantly higher as compared to males ( $\mathrm{p}=0.004)$.

CONCLUSION: The relationship between variables and the three groups has shown a higher number of individuals with more severe symptoms in group III. So, it is understood that migraine is a morbid condition often associated to temporo-

\footnotetext{
1. Universidade Federal de Săo Paulo, Escola Paulista de Medicina, Departamento de Morfologia e Genética, São Paulo, SP, Brasil.

2. Universidade de Santo Amaro, Faculdade de Medicina da Universidade de Santo Amaro, Departamento de Bioestatística, São Paulo, SP, Brasil.

3. Universidade Federal de Sáo Paulo, Escola Paulista de Medicina, Departamento de Neurologia, São Paulo, SP, Brasil.

4. Faculdade São Leopoldo Mandic, Departamento de Disfunçấo Temporomandibular e Dor Orofacial, Campinas, SP, Brasil.

Submitted in September 29, 2015.

Accepted for publication in February 12, 2016.

Conflict of interests: none - Sponsoring sources: CAPES.

\section{Correspondence to:}

Thatiana Bastos Guimarăes

Rua Botucatu, 740 - Vila Clementino

04023-900 São Paulo, SP, Brasil.

E-mail: thatianaguimaraes@uol.com.br

(C) Sociedade Brasileira para o Estudo da Dor
}

mandibular disorders, worsening symptoms referred by patients. There is the need for multidisciplinary evaluation of these individuals to optimize treatment and minimize morbidity, costs and the number of medical visits.

Keywords: Facial pain, Headache, Psychology, Temporomandibular joint, Temporomandibular joint disorders.

\section{RESUMO}

JUSTIFICATIVA E OBJETIVOS: Relacionar as variáveis biopsicossociais do Research Diagnostic Criteria for Temporomandibular Disorders com os grupos de pacientes com disfunçáo temporomandibular, com disfunçáo temporomandibular e migrânea e grupo controle.

MÉTODOS: Estudo do tipo observacional transversal onde foram avaliados 280 pacientes consecutivos, divididos em 3 grupos: grupo I (140 indivíduos controle); grupo II (65 indivíduos com disfunção temporomandibular muscular) e grupo III (75 indivíduos com migrânea e disfunção temporomandibular muscular). Os critérios de exclusão foram indivíduos que apresentaram histórico clínico de processos inflamatórios musculares, espasmos musculares, contraturas e injúria traumática aguda na articulação temporomandibular.

RESULTADOS: Os indivíduos do grupo III apresentaram associação com depressão grave $(\mathrm{p}<0,0001)$, grau 4 na variável intensidade da dor $(\mathrm{p}=0,004)$, sintomas físicos não específicos sem dor intensa $(\mathrm{p}<0,0001)$ e sintomas físicos não específicos com dor intensa $(\mathrm{p}<0,0001)$. Houve diferença significativa entre os gêneros feminino e masculino no grupo III $(Z=2,59 ; p=0,001)$, evidenciando maior tempo de dor no gênero feminino. A porcentagem de mulheres no grupo III foi significativamente maior em relação aos homens $(\mathrm{p}=0,004)$.

CONCLUSÃO: A relação entre as variáveis e os três grupos mostrou maior número de indivíduos acometidos com maior intensidade de sintomas no grupo III. Dessa forma, entende-se que a migrânea é uma condição mórbida frequentemente associada à disfunção temporomandibular, potencializando os sintomas descritos pelos pacientes. Há necessidade de avaliaçóes clínicas multidisciplinares nesses indivíduos para que o tratamento seja otimizado, minimizando a morbidade e diminuindo os custos e o número de consultas prestadas aos pacientes.

Descritores: Articulação temporomandibular, Cefaleia, Dor facial, Psicologia, Transtornos da articulação temporomandibular. 


\section{INTRODUCTION}

Temporomandibular disorder (TMD) is a term encompassing a broad spectrum of clinical orofacial joint and muscles problems. It is especially characterized by pain, temporomandibular joint (TMJ) noises and irregular or limited jaw function, representing a significant reason for non-dental pain in the orofacial region ${ }^{1}$. It is the third most prevalent chronic pain, being more frequent among youngsters and adults (20 to 50 years of age), affecting predominantly females in a female/ male proportion between $3: 1$ and 9:1 $1^{2,3}$. TMD is often associated to other chronic pains, such as headaches, cervical and joint pains, causing major physical and psychological incapacity, in addition to high healthcare costs ${ }^{4,5}$.

The Research Diagnostic Criteria for Temporomandibular Disorders is a valid and reliable method to evaluate and diagnose TMD. It has two axes. Axis I is physical evaluation which subdivides TMD in three groups: myofascial pain (group I), disc displacement (group II) and arthralgia and osteoarthritis (group III). Axis II is a biopsychosocial evaluation and was developed to screen psychological status of patients and classify them in a chronic pain scale. These measures are not intended to make a psychiatric diagnosis, but rather to guide the need for multidisciplinary treatment $^{6}$. Important biopsychosocial variables are age, pain, duration, pain intensity, non-specific physical symptoms and depression ${ }^{7}$.

Most common TMD subtype is muscle TMD (group I) ${ }^{3}$. Patients with muscle TMD report pain in face, jaw, temporal region and ear and often report headaches ${ }^{8,9}$. There is a strong association between TMD and headaches, especially migraine $(\mathrm{MIG})^{10,11}$ and this seems to worsen the disease with more disastrous psychological consequences for patients $s^{5,10}$.

This study aimed at relating RDC axis II variables to groups of patients with TMD, with TMD and migraine and control individuals, aiming at better understanding the importance of migraine in worsening the effects detected by RDC axis II, as well as its importance as coadjuvant factor to temporomandibular disorders.

\section{METHODS}

This is a case-control study where 280 patients were evaluated between January 2013 and January 2014, who were divided in three groups: group I (control) - 140 normal individuals of general population (this population was selected in the Blood Center of Escola Paulista de Medicina, Universidade Federal de São Paulo / Hospital São Paulo( (EPM-UNIFESP-HSP); group II (TMD) - 65 individuals with muscle TMD without migraine and followed up by the Temporomandibular Disorder and Orofacial Pain outpatient setting, EPM-UNIFESP-HSP; and group III - 75 individuals with migraine and temporomandibular disorder assisted by the Neuroheadache Outpatient Setting, EPMUNIFESP-HSP.

Consecutive patients above 18 years of age were included in the study. Patients were informed about procedures and their voluntary participation in the study and have signed the Free and Informed Consent Term (FICT). Initially, all participants were submitted to the European Academy of Craniomandibular Disorders questionnaire ${ }^{12}$. Patients with at least one affirmative answer to the questionnaire were included in the study groups.

For the diagnosis of TMD, patients were evaluated with $\mathrm{RDC} / \mathrm{TMD}^{7}$ by a single qualified investigator and had myofascial pain with or without mouth opening limitation. Migraine was diagnosed by International Classification of Headaches $-3^{\text {rd }}$ edition ${ }^{13}$ criteria, by experienced neurologist being that no individual had chronic migraine.

Exclusion criteria were individuals with previous clinical history of muscle inflammatory processes, muscle spasms, contractures and acute TMJ trauma injury.

Once classified for study groups, patients were submitted to RDC Axes I and II. Axis I involves jaw opening pattern, vertical and horizontal incisal openings, joint noises evaluation and masticatory muscles palpation. Then, patients were submitted to RDC Axis II, which is made up of a questionnaire starting with seven specific questions to quantify chronic pain and incapacity levels in the following scale: level 0 - no pain in the last six month; level I - low incapacity and low pain intensity; level II - low incapacity and high pain intensity; level III - high incapacity and moderate limitation; level IV - high incapacity and severe limitation. Following, there is a list to evaluate jaw incapacity, that is, the extent to which TMD interferes with jaw functions. Finally, the questionnaire includes a list of symptoms, made up of a series of validated tests to evaluate psychic status of depression, non-specific physical symptoms with or without pain, and to classify them as normal, moderate or severe, according to scores described in that manual ${ }^{7}$.

\section{Statistical analysis}

Mann-Whitney test ${ }^{14}$ was used to compare genders with regard to age in each separate group. Kruskal-Wallis analysis of variance ${ }^{14}$ was used to compare groups with regard to age in each gender. Mann-Whitney test ${ }^{14}$ was used to compare groups II and III with regard to pain duration, and pain intensity in both groups was evaluated by Chi-square test ${ }^{14}$. Finally, Chi-square test was applied to compare the three groups with regard to gender, depression, non-specific physical symptoms with and without pain, income and education level. Rejection level of null hypothesis was established as 0.05 or $5 \%$ and data were analyzed by the software SPSS 11.0 for Windows (SPSS Inc., Chicago, IL, USA). This study was approved by the Research Ethics Committee, Universidade Federal de São Paulo/Hospital São Paulo, (CEP UNIFESP/HSP) under CAAE: 06026812.0.0000.5505.

\section{RESULTS}

With regard to age, in the first stage, Mann-Whitney test has shown significant difference between females and males 
in group I, control group $(\mathrm{Z}=2.24 ; \mathrm{p}=0.025)$, with older median age for males. In the second stage, Kruskal-Wallis analysis of variance has shown median age of group I males also significantly older as compared to group II (TMD) and group III (MIG/TMD) $($ Hcalc $=10.30 ; \mathrm{p}=0.006)$. Variables gender, age and pain duration are shown in table 1.

Chi-square test has shown significant difference between genders when compared with regard to the distribution of subjects in the three groups $(\mathrm{p}=0.004)$, showing that the percentage of group III components, in females, was significantly higher as compared to males (Table 1).

Pain duration, evaluated by Mann-Whitney test, has shown significant differences between females and males in group III $(Z=2.59 ; p=0.001)$, showing longer pain duration among females. When groups II and III were compared by the same test, there has been significant difference among females, showing that pain duration for group III females was significantly longer as compared to group II females $(\mathrm{Z}=5.17$; $\mathrm{p}<0.0001$ ) (Table 1).

For not having detected significant differences between genders for variables pain intensity, depression, non-specific physical symptoms with and without pain, table 2 shows groups I, II and III values considering them integrally and for both genders.

Table 1. Distribution of variables gender, age and pain duration in study and control groups

\begin{tabular}{|c|c|c|c|c|}
\hline Variables & $\begin{array}{c}\mathrm{Gl} \\
(\mathrm{n}=140)\end{array}$ & $\underset{(n=65)}{\text { Gll }}$ & $\begin{array}{c}\text { GIII } \\
(n=75)\end{array}$ & $p$ value \\
\hline \multicolumn{5}{|l|}{ Age (yars) } \\
\hline Female (median/mean) & $46 / 43.5$ & $41 / 42.0$ & $46 / 42.0$ & $p=0.751$ \\
\hline Male (median/mean) & $50 / 49.5$ & $36 / 39.0$ & $34 / 38.1$ & $p=0.006$ \\
\hline \multicolumn{5}{|l|}{ Gender } \\
\hline Female (n/\%) & 83 (59.3) & $40(61.5)$ & $61(81.3)$ & $p=0.004$ \\
\hline \multicolumn{5}{|l|}{ Pain duration (months) } \\
\hline Female (median/mean) & & $24 / 50.77$ & $120 / 153.54$ & $\mathrm{p}<0.0001$ \\
\hline Male (median/mean) & & $24 / 91.16$ & $24 / 70.42$ & $p=0.918$ \\
\hline$p$ value & & $p=0.403$ & $p=0.001$ & \\
\hline
\end{tabular}

$\mathrm{GI}$ = control group; GII = muscle temporomandibular disorder; GIII = migraine and muscle temporomandibula disorder

Table 2. Relationship between control and study grouops and biopsychosocial variables of RDC axis II

\begin{tabular}{|c|c|c|c|c|c|c|c|}
\hline \multirow[t]{2}{*}{ Variables } & \multicolumn{2}{|r|}{ GI } & \multicolumn{2}{|c|}{ GII } & \multicolumn{2}{|c|}{ GIII } & \multirow[t]{2}{*}{$p$ value } \\
\hline & $\mathrm{n}$ & $\%$ & $\mathrm{n}$ & $\%$ & $n$ & $\%$ & \\
\hline Pain intensity & & & & & & & $p=0.004$ \\
\hline Level 1 & & & 23 & 35.4 & 20 & 26.7 & \\
\hline Level 2 & & & 29 & 44.6 & 19 & 25.3 & \\
\hline \multicolumn{8}{|l|}{ Depression } \\
\hline Normal & 114 & 81.4 & 37 & 56.9 & 13 & 17.3 & $p<0.0001$ \\
\hline Moderate & 19 & 13.6 & 18 & 27.7 & 24 & 32.0 & \\
\hline Severe & 7 & 5.0 & 10 & 15.4 & 38 & 50.7 & \\
\hline Severe & 17 & 12.1 & 19 & 29.2 & 48 & 64.0 & \\
\hline \multicolumn{8}{|c|}{ NSPS with pain } \\
\hline Normal & 114 & 81.4 & 32 & 49.2 & 11 & 14.7 & $p<0.0001$ \\
\hline Moderate & 13 & 9.3 & 15 & 23.1 & 14 & 18.7 & \\
\hline Severe & 13 & 9.3 & 18 & 27.7 & 50 & 66.6 & \\
\hline
\end{tabular}




\section{DISCUSSION}

Chronic pain is an important public health issue as reported by Johannes et at. ${ }^{15}$ who have shown that approximately one third of the American population had some type of chronic pain lasting at least six months. Similar values were also found in Brazil ${ }^{11}$. RDC has represented a shift in the paradigm of evaluating and diagnosing TMD, because as opposed to previous diagnostic systems, these diagnostic criteria also evaluate biopsychosocial variables in addition to physical aspects ${ }^{7}$. Our study has evaluated the following TMD-associated biopsychosocial factors: age, gender, pain intensity, depression symptoms and non-specific physical symptoms with and without pain.

Table 1 shows that groups are different with regard to age and gender. So, the comparison among groups should be carefully made.

In our sample, even with statistically significant differences with regard to age in group I and when compared to groups II and III, all groups had ages compatible with those described in the literature, showing that the most prevalent age group of affected patients is from 20 to 50 years of age $^{3}$, corresponding to the period in which people have higher emotional concerns with financial and family issues. So, we have considered that stress of economically active age group is a contributing factor for pain worsening.

A common feature of TMD and migraine is the role of female hormones in symptoms duration and severity ${ }^{16-18}$. There are evidences that the association between migraine and TMD in females may be due to genetic susceptibility factors shared by both conditions or even to biopsychosocial factors which, associated to the former, would contribute to make the presentation more evident ${ }^{5,17,19,20}$. With regard to gender, it was also observed a higher number of females as compared to males in all groups, especially group III.

Groups II and III had higher levels in the pain intensity scale and this result is in line with the literature, because the presence of TMD in migraine patients leads to migraine persistence and chronicity, thus increasing pain intensity ${ }^{10}$. In addition, the presence of primary headache together with TMD negatively influences the management of $\mathrm{TMD}^{21}$. The association between severe depression and non-specific physical symptoms and group II observed in this study is in line with an Italian study which has shown that when there is muscle TMD and migraine, there is major impairment of the psychological status of individuals, determining high levels of somatization ${ }^{22}$.

By identifying modifiable behavioral factors, such as stress or diet handling, in addition to the evaluation of genetic, environmental, social and cultural factors involved in the relationship between TMD and migraine, this might be prevented with management strategies for both conditions $s^{5}$. The coexistence of several pain condi- tions may explain why $50 \%$ of individuals looking for TMD management still report pain 5 years after and $20 \%$ have chronic incapacity ${ }^{23}$.

\section{CONCLUSION}

The relationship between RDC axis II variables and the three evaluated groups has led to a larger number of affected individuals and more severe symptoms in group III. So, we understand that migraine is a morbid condition often associated to TMD and that, when present, may potentiate symptoms referred by patients. So, we emphasize the need for multidisciplinary clinical evaluations in individuals with both conditions to adequately establish diagnosis and that management strategy and time are optimized to minimize morbidity and decrease costs and number of consultations of affected patients.

\section{REFERENCES}

1. Carlsson GE, Magnusson T, Guimarães AS. Tratamento das disfunçôes temporomandibulares na clínica odontológica. $1^{\text {a }}$. ed. São Paulo: Quintessence; 2006.

2. Köhler AA, Hugoson A, Magnusson T. Clinical signs indicative of temporomandibular disorders in adults: time trends and associated factors. Swed Dent J. 2013;37(1):111.

3. Scrivani SJ, Keith DA, Kaban LB. Temporomandibular disorders. New Engl J Med. 2008;359(25):2693-705.

4. Ballegaard V, Thede-Schmidt-Hansen P, Svensson P, Jensen R. Are headache and temporomandibular disorders related? A blinded study. Cephalalgia. 2008;28(8):832-41.

5. Plesh O, Noonan C, Buchwald DS, Goldberg J, Afari N. Temporomandibular disorder-type pain and migraine headache in women: A preliminary twin study. J Orofac Pain. 2012;26(2):91-8.

6. Dworkin SF, Sherman J, Mancl L, Ohrbach R, LeResche L, Truelove E. Reliability, validity, and clinical utility of the research diagnostic criteria for Temporomandibular Disorders Axis II Scales: depression, non-specific physical symptoms, and graded chronic pain. J Orofac Pain. 2002;16(3):207-20.

7. Dworkin SF, LeResche L. Research diagnostic criteria for temporomandibular disorders: review, criteria, examinations and specifications, critique. J Craniomandib Disord. 1992;6(4):301-55.

8. Anderson GC, John MT, Ohrbach R, Nixdorf DR, Schiffman EL, Truelove ES, et al Influence of headache frequency on clinical signs and symptoms of TMD in subjects with temple headache and TMD pain. Pain. 2011;152(4):765-71.

9. Svensson P. Muscle pain in the head: overlap between temporomandibular disorders and tension-type headaches. Curr Opin Neurol. 2007;20(3):320-5.

10. Bevilaqua-Grossi D, Lipton RB, Napchan U, Grosberg B, Ashina S, Bigal ME. Temporomandibular disorders and cutaneous allodynia are associated in individuals with migraine. Cephalalgia. 2010;30(4):425-32.

11. Gonçalves DA, Camparis CM, Speciali JG, Franco AL, Castanharo SM, Bigal ME Temporomandibular disorders are differentially associated with headache diagnoses: A controlled study. Clin J Pain. 2011;27(7):611-5.

12. De Boever JA, Nilner M, Orthlieb JD, Steenks MH. Educational Committee of the European Academy of Craniomandibular Disorders: Recommendations by the EACD for examination, diagnosis, and management of patients with temporomandibular disorders and orofacial pain by the general dental practitioner. J Orofac Pain. 2008;22(3):268-78.

13. Headache Classification Committee of the International Headache Society (IHS). The International Classification of Headache Disorders, $3^{\text {rd }}$ ed. (beta version). Cephalalgia. 2013;33(9):629-808

14. Siegel SE, Castellan JR. Estatística năo paramétrica para ciências do comportamento. 2a. ed. Porto Alegre: Artmed; 2006.

15. Johannes CB, Le TK, Zhou X, Johnston JA, Dworkin RH. The prevalence of chronic pain in United States adults: results of an Internet-based survey. J Pain. 2010;11(11):1230-9.

16. Hassan S, Muere A, Einstein G. Ovarian hormones and chronic pain: a comprehensive review. Pain. 2014;155(12):2448-60.

17. Kang SC, Lee DG, Choi JH, Kim ST, Kim YK, Ahn H J. Association between estrogen receptor polymorphism and pain susceptibility in female temporomandibular joint osteoarthritis patients. Int J Oral Maxillofac Surg. 2007;36(5):391-4.

18. Licini F, Nojelli A, Segu M, Collesano V. Role of psychosocial factors in etiology of temporomandibular disorders: relevance of a biaxial diagnosis. Minerva Stomatol. 
2009;58(11-12):557-66.

19. Cairns BE, Gazerani P. Sex related differences in pain. Maturitas. 2009;63(4):292-6.

20. Peterlin BL, Gupta S, Ward TN, MacGregor A. Sex matters: evaluating sex and gender in migraine and headache research. Headache. 2011;51(6):839-42.

21. Porporatti AL, Costa YM, Conti PC, Bonjardim LR, Calderon PD. Primary headaches interfere with the efficacy of temporomandibular disorders management. J Appl Oral Sci. 2015;23(2):129-34.
22. Cioffi I, Perrotta S, Ammendola L, Cimino R, Vollaro S, Paduano S, et al. Social impairment of individuals suffering from different types of chronic orofacial pain. Prog Orthod. 2014;15(1):27.

23. Velly AM, Look JO, Schiffman E, Lenton PA, Kang W, Messner RP, et al. The effect of fibromyalgia and widespread pain on the clinically significant temporomandibular muscle and joint pain disorders--a prospective 18-month cohort study. J Pain. 2010;11(11):1155-64. 